\title{
FACTORS INFLUENCING THE EXISTENCE TINUTUAN CULINARY IN EATING PATTERN AMONG FAMILIES IN MANADO, NORTH SULAWESI
}

\author{
Grace Kerly Lony Langi \\ School of Health Polytechnics, Ministry of Health, Manado
}

\begin{abstract}
Background: Tinutuan (Manado porridge) culinary has developed and changed over decades from its original food mix. But its nutritional value did not change and its beneficial effect on health continued to increase. With the influence of globalization that introduced fast food eating pattern among families, tinituan culinary did not lose its identity and remained to exist as an urban consumption life style. This study aimed to determine factors influencing the existence of tinutuan culinary eating pattern among families in Manado, North Sulawesi.

Subjects and Method: This was a qualitative study conducted in Manado, North Sulawesi. A number of informants were selected purposively. The data were collected by direct observation, in-depth interview, and literature review. Cultural studies theories were used for data analysis.

Results: Health value, religious custom, socio-economic status, and taste factors influenced the existence of tinutuan culinary. There was an image that made tinutuan culinary eating pattern had not been presented as the party menu in all social strata.

Conclusion: The existence of traditional tinutuan culinary is affected by health value, religious custom, social-economic status, and taste factors. It is recommended that inherited tinutuan culinary eating pattern within the families be maintained to develop.
\end{abstract}

Keywords: tinutuan culinary, eating pattern, health value, religious custom

Correspondence: Grace Kerly Lony Langi. School of Health Polytechnics, Ministry of Health, Manado, North Sulawesi. Email: kllge@yahoo.com. Mobile: +6285333771065. 